\title{
ASSESSMENT OF SELECTED METALS IN THE MUSCLE AND LIVER OF THE AFRICAN CATFISH (CLARIAS GARIEPINUS) COLLECTED FROM ILUSHI RIVER, ILUSHI, EDO STATE, NIGERIA.
}

\author{
Izegaegbe, Joshua Idowu ${ }^{1 *}$ and Oloye, Femi Francis ${ }^{2}$ \\ ${ }^{1}$ Department of Zoology, Ambrose Alli University, Ekpoma, Nigeria \\ ${ }^{2}$ Department of Chemistry, Adekunle Ajasin University, Ondo State Nigeria. \\ *Corresponding Author: \\ Email joshizegs@gmail.com, joshua.izeg@gmail.com Telephone +2348037379828 \\ (Received: 1st June, 2016; Accepted: 27th May, 2017)
}

\section{ABSTRACT}

\begin{abstract}
This study determined the level of manganese, zinc, copper, and nickel in the liver and muscle of the African Catfish, Clarias gariepinus from Ilushi River, Edo State, Nigeria with a view to determining the level of heavy metal contamination. The results showed that the muscles and the livers contained varying levels of the assayed selected heavy metals and non-metallic elements. The heavy metal load assayed revealed that zinc had the highest mean concentration $(0.217 \pm 0.008 \mu \mathrm{g} / \mathrm{g})$ in liver and $(0.130 \pm 0.006 \mu \mathrm{g} / \mathrm{g})$ in muscle, Copper had the least concentration $(0.063 \pm 0.004 \mu \mathrm{g} / \mathrm{g})$ in liver and $(0.027 \pm 0.003 \mu \mathrm{g} / \mathrm{g})$ in muscle. The distribution of the heavy metals in the muscles and livers of Clarias gariepinus showed significant variations with the concentration of the heavy metals being higher in the liver than in the muscle of fish. Comparison with WHO/FAO/FEPA/USFDA permissible limit revealed that the concentrations of the assayed heavy metals in the fish were safe for human consumption.
\end{abstract}

Keywords: Clarias gariepinus, Heavy Metals, Liver, Muscle.

\section{INTRODUCTION}

Heavy metals which are metallic elements of high densities could be regarded as potentially toxic, semi-essential or non-essential (Szentmihalyi and Then, 2007). Ecotoxicological studies place significant concern on the category of heavy metals known as essential and non-essential due to their persistency and relative toxicity to flora and fauna (Storelli et al., 2005). The ubiquitous nature of heavy metals allows them to be rapidly dissolved in water and be readily conveyed into tissues of aquatic biota (Alam et al., 2002).

Aquatic environments are the repository of contaminants notably heavy metals, which are ploughed back into the food chains through bioaccumulation in plankton, invertebrates, fishes and finally biomagnified in man (Edward et al., 2013). The buildup and elevation of heavy metals can potentially become toxic to aquatic biota like fish at very low exposure contact (Ekeanyawu et al., 2010). Several anthropogenic activities and geologic processes such as disposal of waste effluents and utility waste from industries and agrochemicals influence the introduction of heavy metal contaminants into aquatic systems (Adefemi et al., 2004). Fish biota have been recognized as suitable bio-indicator in the assessment of heavy metal contamination in aquatic systems (Papagiannis et al., 2004), largely due to the ease of accumulation through uptake of metals in water and diet.

Several studies on heavy metal contamination in fish have been widely reported (Fernandes et al., 2008, Praveena et al., 2008, Öksüz et al., 2009, Yildirim et al., 2009). Also, studies have reported on the effects of these contaminants on some aquatic organisms. Studies have also related increased levels of heavy metals accumulated within human bodies to the consumption of heavy metals tainted organisms. In this study, heavy metals pollution was assessed from the muscles and liver of the African Catfish caught from Ilushi River in Edo State, southern Nigeria. The study will provide baseline data on the metal concentrations in organs of widely consumed African Catfish collected from an area known for crude oil prospecting.

\section{MATERIALS AND METHODS \\ Study Area}

This study was conducted in Ilushi River, in the Ilushi community, Esan South East Local Government Area of Edo State, Nigeria. Ilushi is a predominantly fishing community whose river is 
a source of water used for both domestic and industrial purposes. This particular river is known to serve as a major distribution point for the sales of freshwater fish species due to the proximity to the Ilushi market. However, the Ilushi river, which is rural based receives effluent from a local cassava industry as well as from associated human related activities which potentially impacted the pristine ecosystem.

\section{Samples Collection}

A total of 28 live and apparently healthy $C$. gariepinus specimens were collected from different points along the course of the river. An average of 6-8 fishes was collected from each point using cast nets deployed by local fishermen. The fishes were conveyed to the laboratory in plastic container with water from the river early in the morning to avoid undue stress due to temperature rise. The samples were packaged in sterile plastic containers and frozen in deep freezers at $-10^{\circ} \mathrm{C}$ prior to preparation and processing.

\section{Sample Preparation and Analysis:}

Fish samples were carefully cut open using a plastic knife and the muscles and liver of the fish were dissected out. Approximately $5 \mathrm{~g}$ of wet tissue was weighed into an Erlenmeyer flask and $50 \mathrm{ml}$ of $\mathrm{HNO}_{3}$ was added together with $20 \mathrm{ml}$ of $\mathrm{H}_{2} \mathrm{SO}_{4}$ and mixture shaken together and boiled until all organic matters were destroyed. The digest was allowed to cool and $75 \mathrm{ml}$ of water was added to the mixture which turned pale yellow on observation. Twenty five (25) $\mathrm{ml}$ of a saturated solution of ammonium oxalate was added to the mixture and was evaporated to remove excess sulphuric acid $\left(\mathrm{H}_{2} \mathrm{SO}_{4}\right)$. The mixture was allowed to cool and was then diluted with water and was further transferred to a $500 \mathrm{ml}$ volumetric flask and made up to mark with de-ionized water. The digests were kept in a plastic bottle and were analyzed for selected heavy metals (manganese, copper, zinc and nickel). The biogenic ions $(\mathrm{Na}, \mathrm{K}$, $\mathrm{Ca}, \mathrm{Mg}, \mathrm{P}$ ) were determined using air acetylene flame atomic absorption spectrophotometer (Perkin Elmer A.A310).

\section{Statistical Analysis:}

The data obtained which were presented as means \pm standard error of means were subjected to Analysis of Variance using an instant statistical package (Origin pro 8.1)

\section{RESULTS AND DISCUSSION}

The heavy metal concentrations in muscle and liver of C. gariepinus (Figure 1) revealed that liver accumulated high amount (almost twice) of $\mathrm{Cu}$ and $\mathrm{Zn}$ than the muscle. The result obtained was consistent with other studies which revealed that heavy metal accumulated more in liver than any other part of fish (Aladesanmi and Awotoye, 2014). The distribution pattern of heavy metals reported was liver $>$ gills $>$ muscle $>$ fins (Aladesami and Awotoye, 2014) which indicated that liver of Clarias gariepinus was more receptive to heavy metal accumulation than the muscles (Ekpo et al., 2008; Yilmaz, 2009). The findings was also consistent with the report of Edem et al (2009) which showed that heavy metals were concentrated more in the liver than in other parts of fish organs.

A slightly different result was obtained during the study with $\mathrm{Mn}$ and $\mathrm{Ni}$, which were accumulated in nearly the same quantity in the liver and muscle of the fish. However, Mn was slightly higher in liver when compared to muscular concentration. Habib and Dayyab (2014) also observed that manganese and nickel were not detected in muscle of Clarias gariepinus collected from Challawa river. All these observations recorded were consistent with the findings from the current study that muscles of Clarias gariepinus was probably not an active organ in the accumulation of heavy metals as the concentrations of assayed heavy metals in liver were significantly higher $(\mathrm{P}<0.05)$ for all the metals when compared to the fish muscles. Heavy metals accumulate in the liver probably due to the highly vascularised conditions which facilitates metal absorption unlike the muscles.

Analyses of the results showed that the concentrations of copper and zinc in the fish fell below permissible limits (FAO, 1983; FDA, 2001; FEPA, 2003) (Table 1) and thus do not necessarily pose any human health risk. However, the manganese concentrations both in liver and muscle recorded in the fish were slightly above permissible limit of USFDA and FEPA (FDA, 2001; FEPA, 2003) (Table 1).

The concentrations of the selected non-heavy metals $(\mathrm{P}, \mathrm{K}, \mathrm{Na}$, and $\mathrm{Mg}$ ) are shown in Figure 2. 
The results revealed that unlike the heavy metals, non-heavy metals accumulated more in the muscles in all cases. The trend at which non-heavy metals accumulated were: $\mathrm{K}>\mathrm{Na}>\mathrm{P}>\mathrm{Mg}$. The level of potassium in muscle was about thrice the concentration in liver. The non-heavy metals were most probably preferably accumulated in muscle while heavy metals were probably preferentially absorbed in liver.

Table 1: Comparative permissible limits of assayed heavy metal concentrations $(\mu \mathrm{g} / \mathrm{g})$ in animal tissues

\begin{tabular}{|l|l|l|l|l|}
\hline $\begin{array}{l}\text { Heavy } \\
\text { metal }\end{array}$ & $\begin{array}{l}\text { FAO } \\
(1983)\end{array}$ & $\begin{array}{l}\text { WHO } \\
(1989)\end{array}$ & $\begin{array}{l}\text { USFDA } \\
(2001)\end{array}$ & $\begin{array}{l}\text { FEPA } \\
(2003)\end{array}$ \\
\hline $\mathrm{Cu}$ & 30.0 & 2.0 & 1.3 & $0.5-1.5$ \\
\hline $\mathrm{Zn}$ & 30.0 & 3.0 & 5.0 & $5-10$ \\
\hline $\mathrm{Mn}$ & 1.0 & 0.5 & 0.05 & 0.05 \\
\hline $\mathrm{Ni}$ & 10.0 & 0.02 & $0.07-0.08$ & $0.5-0.6$ \\
\hline
\end{tabular}

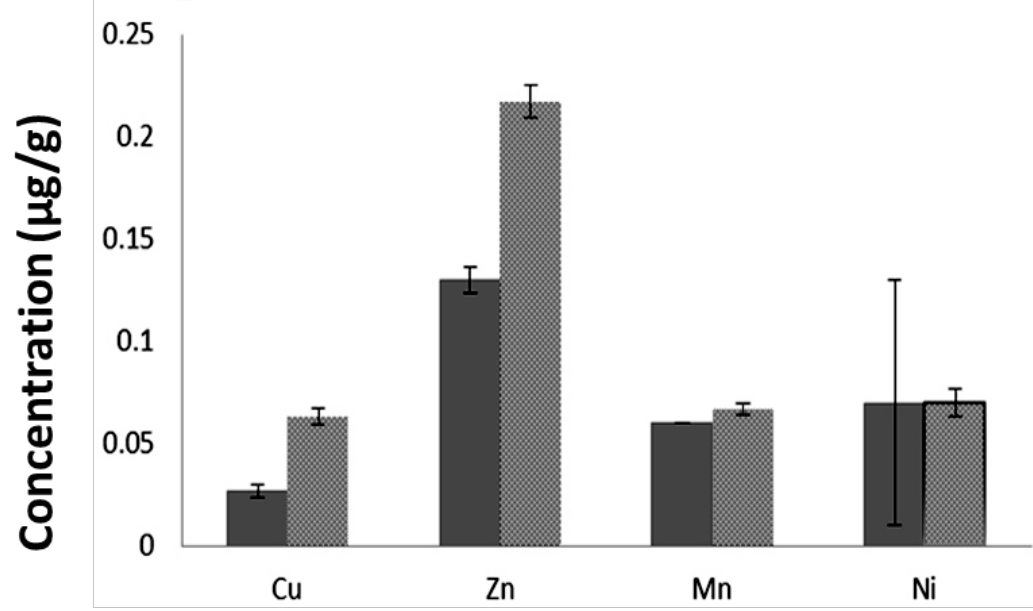

Elements

Figure 1: Heavy metal concentration in muscle (blue) and liver (red) of Clarias gariepinus

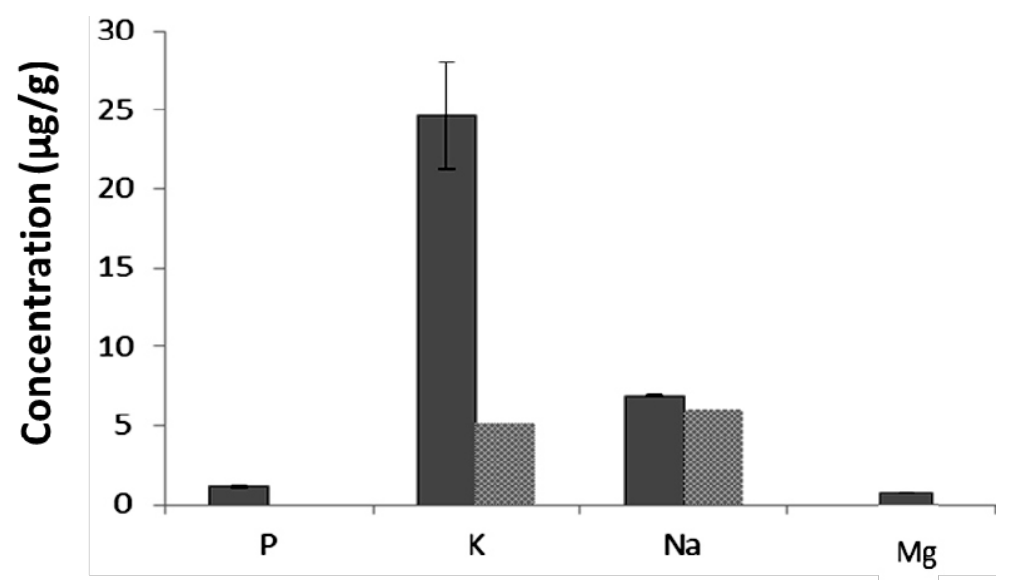

Elements

Figure 2: Non heavy metal concentration in muscle (blue) and liver (red) of Clarias gariepinus 


\section{CONCLUSION}

In this study, heavy metals were preferentially accumulated in liver while the non-heavy metals were preferentially accumulated in the muscle. The heavy metals investigated in this study were found to be below permissible regulatory limits. However, before it can be conclusively stated that C. gariepinus in the area are safe for consumption, more samples should be analyzed and periodic check undertaken to ensure the heavy metal concentrations are below permissible limits. Also, there is need to ascertain the bioaccumulation potential of other organs such as kidney, gills, stomach for comprehensive status of heavy metals accumulation in the fish.

\section{REFERENCES}

Adefemi, O.S., Asaolu, S.S and Olaofe, O.O., 2004. Concentration of heavy metals in water, sediment and fish parts of Ureje Dam, Ado-Ekiti, Nigeria. Journal of Biological and Physical Sciences 1: 114-117.

Aladesanmi, O., and Awotoye, O.O., 2014. Bioaccumulation of heavy metals in fish (Clarias gariepinus) organs from selected streams in South Western Nigeria. $2^{\text {nd }}$ International Conference on Sustainable Environment and Agriculture, Singapore. IPCBEE 76: 47-50.

Alam, M.G.M., Tanaka, A., Allison, G., Laurenson, L.J.B., Stagnitti, F., and Snow, E.T., 2002. A comparison of trace element concentration in cultured and wild carp (Cyprinus carpio) of Lake Kasumigaura, Japan. Ecotoxicology and Environmental Safety 53: 348-354.

Edem, C.A., Osabor, V., Iniama, G., Etuma, R., and Eke, J., 2009. Distribution of heavy metals in bones, gills, liver and muscles of (Tilapia) Oreochromis niloticus from Henshaw Town market, in Calabar, Nigeria. Pakistan Journal of Nutrition 8 (8): 1209-1211.

Edward, J.B., Idowu, E.O., Oso, J.A., and Ibidapo, O.R., 2013. Determination of heavy metal concentration in fish samples, sediment and water from Odo-Ayo River in AdoEkiti, Ekiti- State, Nigeria. International Journal of Environmental Monitoring and Analysis 1(1): 27-33.

Ekeanyanwu, C.R., Ogbuinyi, C.A., and
Etienajirhevwe, O.F., 2010. Trace metals distribution in fish tissues, bottom sediments and water from Okumeshi River in Delta State, Nigeria. Ethiopian Journal of Environmental Studies and Management 3(3): 12-17.

Ekpo, K.E., Asia, I.O., Amayo, K.O., and Jegede, D.A., 2008. Determination of lead, cadmium and mercury in surrounding water and organs of some species of fish from Ikpoba River in Benin City, Nigeria. International Journal of Physical Science 3(11): 289-292.

FAO (Food and Agriculture Organization), 1983. Compilation of legal limits for harzardous substances in fish and fishery products. FAO Fisheries Circular N0 466, pp 5-100.

FDA (Food and Drug Administration), 2001. Fish and fisheries Products Hazards and Control Guidance. $3^{\text {rd }}$ Edn., Center for Food Safety and Applied Nutrition, US Food and Drug Administration. 476pp.

FEPA (Federal Environmental Protection Agency), 2003. Guidelines and Standards for Environmental Pollution and Control in Nigeria. 238pp.

Fernandes, C., Fontainhas-Fernandes, A., Cabral, D., and Salgado, M.A., 2008. Heavy metals in water, sediment and tissues of Liza saliens from Esmoriz-Paramos Lagoon, Portugal. Environmental Monitoring Assessment 136(1-3):267-275.

Habib, Y. Tasheed, and Dayyab, M.S., 2014. Levels of some heavy metals in six species of fish obtained from Challawa River, Kano, Nigeria. International Journal of Biological and Chemical Science 8(1): 413-418.

Oksuz, A., Ozyilmaz, A., Aktas, M., and Motte, J., 2009. A Comparative study on proximate, mineral and fatty acid compositions of Deep Seawater Rose Shrimp (Parapenaeus longirostris, Lucas 1846) and golden Shrimp (Plesioni kamartia, A. MilneEdwards, 1883). Journal of Animal Veterinary Advances 8(1): 1183-189.

Papagianus, I., Kagalou, I., Leonardos, J., Petridis, D., and Kelfakaou, V., 2004. Copper and zinc in four freshwater fish species from Lake Pamvotis (Greece). Environmental International30: 357-362.

Praveena, S.M., Radojevic, M., Abdullah, M.H., 
and Aris, A.Z., 2008. Application of sediment quality guidelines in the assessment of mangrove surface sediment in Mengkabong Lagoon, Sabah, Malaysia. Iranian Journal of Environmental Health Science and Engineering 5(1): 35-42.

Storelli, M.M., Storelli, A., D'ddaabbo, R., Morano, C., Bruno, R., and Marcotrigiano, G.O., 2005. Trace elements in Loggerheads turtles (Caretta caretta) from the eastern Mediterranean Sea: Overview and Evaluation. Environmental Pollution 135: 163-170.

Szentmihalyi, K., and Then, M., 2007. Examination of micro elements in medicinal plants of the carpathian basin. ACTA Alimentaria 36: 231-236.
WHO (World Health Organization), 1989. National Research Council Recommended Dietary Allowances, $10^{\text {th }}$ Edn, National Academy Press: Washington DC, USA

Yildirum, Y., Gonulalan, Z., Narin, I., and Soylak, M., 2009. Evaluation of trace heavy metal levels of some fish species sold at retail in Kayseri, Turkey. Environmental Monitoring Assessment 149: 223-228.

Yilmaz, F. 2009. The comparison of heavy metal concentration $(\mathrm{Cd}, \mathrm{Mn}, \mathrm{Cu}, \mathrm{Pb}$ and $\mathrm{Zn})$ in tissues of three economically important fish (Anguilla anguilla, Mugil cephalus and Oreochro mis niloticus) inhabiting Koycegiz Lake- Mugla (Turkey). Turkish Journal of Science and Technology 4(1): 7-15. 